\title{
The Performance of Jumantik in Treating DHF Virus in Tembalang Sub-district, Semarang
}

\author{
Nina Widowati \\ \{ninawidowati.fisip@gmail.com\} \\ Universitas Diponegoro, Indonesia
}

\begin{abstract}
The purpose of this study is to describe the role of the Jumantik in monitoring mosquito larvae at Tembalang Sub-district, Semarang. This sub-district has the highest dengue cases in 2019. To overcome the cases, the sub-district empowers Jumantik (the trained volunteer to monitor mosquito larvae). The method of the research was descriptive qualitative. The subjects were the Jumantik who lived in Tembalang District. The result shows that the Jumantik performance can be seen from (1) quality of the work, (2) quantity of work completed, (3) time period needed to complete the work, (4) effectiveness of resources, (5) independence in completing the task and (6) work commitment.
\end{abstract}

Keywords: Performance, Quality, Quantity, Independence, Commitment

\section{Introduction}

Health is a priceless gift from the God. People try to maintain their healthy lifestyle in various ways, either through exercising, or keeping the environment healthy. The rainy season in tropical countries such as Indonesia is one of the causes of the emergence of dengue fever suffered by children and adults. One of the diseases that is still highly transmitted is dengue hemorrhagic fever. This disease comes from the bite of the Aedes mosquito that carries the dengue virus. Patients who are exposed to the virus will experience symptoms such as fever, abdominal pain, vomiting, shortness of breath, and decreased platelets that can lead to internal bleeding.

For the prevention of dengue fever outbreaks, the Minister of Health has issued a decree number 581/MENKES/SK/VII/1992 concerning the eradication of dengue fever and is followed up by the Decree of the Minister of Health number 92 of 1994 concerning amendments to the attachment to the Decree of the Minister of Health number 581/MENKES/SK/1992 concerning the movement to eradicate mosquito nests. The ministerial decree regulates the control of dengue fever in Indonesia. The decree emphasizes prevention efforts by eradicating mosquito breeding grounds, as well as strengthening health services and resources.

One of the implementations of these decrees is community empowerment. Community empowerment efforts are carried out by carrying out the Mosquito Nest Eradication Movement (this movement is called PSN 3M Plus), namely draining, closing water reservoirs, recycling and reusing used goods, sprinkling larvae of larvae, raising fish, replacing water in flower vases periodically, and others. 
Tembalang is one of the sub-districts that is densely populated and has a very high case of dengue fever. From January to March 2019, there were 140 cases of dengue fever, of which five were declared dead. Information from the Head of Disease Prevention and Management of the Semarang City Health Office, there were 34 cases of dengue fever in Tembalang (Ayo Semarang.com, Saturday 2/3/20190). The Health Office has attempted to take preventive measures by providing outreach to the public. Through the role of the PKK (Family Welfare Empowerment), a dengue fever prevention program is promoted in the community by involving the trained volunteers of larvae observer (Jumantik). The tasks of Jumantik include: (1) checking water reservoirs, both outside the house and inside the house to ascertain whether there are larvae or not; (2) instructing members of the public not to hang clothes indoors for a long time because these clothes can become mosquito breeding grounds; (3) checking the fish pond for the presence of mosquito larvae; (4) check the whereabouts of uninhabited houses to ascertain whether there is any standing water in the house. Jumantik will report to the subdistrict, sub-district and then will report to the relevant agency. Jumantik in Tembalang subdistrict works according to established procedures, but in reality, cases of dengue fever are still high.

\section{Methodology}

The design of this study is a qualitative descriptive study, which aims to describe the performance of Jumantik in monitoring mosquito larvae in Tembalang sub-district, Semarang City. Respondents were 5 female Jumantik aged 25-40 years selected through community deliberations and determined by the head of the neighborhood unit. They were high school or undergraduate housewives who worked voluntarily, only getting stationery, larva monitoring equipment, uniforms, and transportation costs. They were selected using accidental sampling due to their comfortable accessibility and emotional closeness to the researcher. Data sources are divided into primary and secondary data. Primary data obtained directly from the source, namely the Jumantik who was on duty in monitoring larvae in Tembalang. Secondary data were obtained from related agencies, from literature and document studies relevant to the problem of the study. Data collection techniques used observation, and interviews.

\section{Results and Discussion}

Performance is interpreted by many experts as work performance. The concept of performance is also defined broadly, both at the individual level, in the process, and at the organizational level. All three are equally important and interrelated to achieve goals. Performance will not get results without the ability and competence of a person to carry out their duties. A person's ability is determined by his skills, experience and mental attitude. An individual person can actually work professionally, obey applicable rules, and ethically, but the intervention from outside the environment often makes a person unable to work as expected. The concept of performance according to Rummler and Brache in Sudarmanto [1] states that there are three levels of performance, namely organizational performance, process performance and individual performance. In order to produce performance as expected, it is necessary to have a performance appraisal, which consists of the following steps: review and appraisal, record the assessment, and provide feedback to employees [2]. The basis for this 
performance appraisal aims to: (1) foster and improve performance; (2) identify training and opportunities for development; (3) developing ways of overcoming work barriers and obstacles; (4) establish an agreement between the supervisor and the employee regarding their expectations.

This study refers to the opinion of Robbins [3] that individual performance has six indicators, namely:

a) Quality. The quality of work is measured by Jumantik's perception of the quality of work produced, for his direction to the community to always live clean and implement $3 \mathrm{M}$, so that the larva evaluation results are negative.

b) Quantity. Quantity is the number of activities achieved by Jumantik in monitoring larvae in the community according to the set target.

c) Ontime. Punctuality is the level of activity that can be completed in accordance with the predetermined weekly target.

d) Effectiveness, namely the maximum level of use of energy, money and technology in monitoring larvae in the community.

e) Independence, namely the activity of Jumantik without depending on other people in monitoring larvae in society.

f) Work commitment, namely the commitment that Jumantik has in carrying out his duties and responsibilities in monitoring larvae in the community.

Larva observers or what we usually call Jumantik are members of the community who voluntarily monitor the presence of Aedes Aegypti mosquito larvae in their environment. They are responsible for encouraging the community to eradicate mosquito nests on a regular basis. Jumantik received special training in an effort to handle larva monitoring. The role of Jumantik in handling dengue fever cases is to invite the community to maintain the cleanliness of the environment and their homes, and to monitor larvae independently, and to record on the larva monitoring form that is in each resident's house.

The responsibilities of Jumantik in Tembalang are:

a) Socializing the mosquito nests eradication movement (PSN) with $3 \mathrm{M}$ plus, which consists of draining or cleaning places where water reservoirs often occur, such as bathtubs, buckets, dispensers, aquariums, etc. to homeowners.

b) Inspecting and monitor mosquito breeding places, both inside and outside the house,

c) Mobilizing household members of the household to do cleaning once a week.

d) Recording the results of monitoring larvae and the implementation of PSN with 3M Plus on the larva card.

Jumantik coordinators are selected from community members based on suggestions from the local community, with the following criteria: (1) come from local RT residents, (2) are able and willing to carry out their duties and responsibilities, (3) are able and willing to be a motivator for the local community residence, (4) able and willing to cooperate with officers and community leaders in their environment.

This article will discuss the existence of Jumantik's performance in tackling the dengue fever virus in Tembalang District, which is seen from several aspects, namely quality of work, quantity, timeliness, effectiveness, independence, work commitment. The results of research on the performance indicators of Jumantik in Tembalang, obtained the following description:

\subsection{Work Quality}

The quality of work is measured by Jumantik's perception of what is produced, based on his direction to the community to always live cleanly and implement draining, covering and 
burying so that the larva evaluation results are negative. In addition, Jumantik is in charge of making activity reports to the coordinator. Once a week, Jumantik will visit homes to monitor the whereabouts of larvae. Jumantik in carrying out his duties is followed by local residents as a companion. From the results of the interview with the Jumantik coordinator, Tembalang District, it can be seen that the quality of Jumantik's work is generally in accordance with the specified program and target, it's just that the report is still not neat. This is due to the large number of forms that must be filled in, making Jumantik have to set aside separate time to make the report.

\subsection{Quantity}

Quantity, is the number of activities achieved by Jumantik in monitoring larvae in the community, is it according to the target. In monitoring larvae in the field, the targets are often not as expected. This is because there are several houses that cannot be entered because the occupants leave, or the houses designated for boarding houses are often locked. Tembalang sub-district is an area that has uneven terrain, apart from a dense population, so because monitoring is carried out for only one day, the results are less than the target. In reality on the ground, the houses visited are often random, due to insufficient time to carry out overall monitoring. Through WhatsApp, information is usually provided to residents to prepare houses for officers to visit. Even though there is information on larva monitoring, there are also houses that are suspected of having larvae.

\subsection{Punctuality}

Punctuality is the level of Jumantik activity that can be completed in accordance with the predetermined weekly target. Jumantik conducts larva monitoring every Friday starting at 08.00 to residents' houses. The existence of limited time and limited human resources, causing insufficient time available to monitor all residents, resulting in residents' disappointment because they did not have time to be visited by Jumantik. They feel disappointed, because the results of cleaning the house do not get an assessment. After conducting monitoring, Jumantik immediately made a report. The results of monitoring larvae and the implementation of $3 \mathrm{M}$ PSN are recorded on larva cards. The results of larva monitoring are reported to the Jumantik supervisor once a month. In reality on the ground, Jumantik reports are often late and not on time. This of course has an effect on the data that goes to the Effectiveness is the level of use of energy, money, technology, which is maximized in monitoring larvae in society. So far, the use of larva monitors in Tembalang District is in accordance with existing procedures. Jumantik cadres and coordinators come from community members in Tembalang District, Semarang City based on suggestions from the local RT. Jumantik working procedure refers to implementation instructions and technical instructions for eradicating dengue hemorrhagic fever mosquito nests. In carrying out his duties, Jumantik is given transport fees, larva monitoring equipment, such as hats, vests, briefcases, stationery, flashlights and others according to their needs. Coordination in implementation in the field often uses cell phones.

\subsection{Independence}

Independence is a Jumantik activity without depending on other people in monitoring larvae in society. In implementing larva monitoring in Tembalang Jumantik District, local residents are accompanied to enter residents' houses. Independence can be seen from 
Jumantik's alertness in monitoring larvae in the bathtub, in buckets, in used cans, and in flower pots. After completing checking the condition of the larva, it will be written down in the larva card that is in each resident's house, whether the larva is found or not. Usually the facilitator also monitors, records, and then the results of the monitoring will be informed to local residents. For houses that still have larvae, they will be given a separate note and are advised to immediately clean up. The monitoring results will then be reported to the Jumantik coordinator.

\subsection{Work Commitment}

Work commitment, is a commitment that Jumantik has in carrying out his duties and responsibilities in monitoring larvae in the community. In carrying out monitoring of larvae, Jumantik is very patient and responsible for completing their duties. This can be seen from the consistency of carrying out tasks every Friday, as well as acting as an educator to the community as well as providing information to the Community Health Center. Jumantik knows his job well. The tasks carried out by Jumantik consist of: (1) socializing the eradication of mosquito nests by carrying out $3 \mathrm{M}$ plus, namely sprinkling larvicide powder on water reservoirs that are difficult to clean; using mosquito repellent; using a mosquito net while sleeping, raising mosquito larvae predatory fish, planting mosquito repellent plants. (2) inspect / monitor mosquito breeding places, tubs inside and outside the house once a week, (3) mobilize family members/residents to carry out the PSN Plus $3 \mathrm{M}$ and (4) the results of monitoring are recorded on larva cards.

\section{Conclusion}

Jumantik is a group of volunteers whose duty is to monitor larvae in residents' homes that can cause dengue hemorrhagic fever. Its task is to provide counselling to the community, monitor larvae in each house, and report the results of the monitoring to the Jumantik coordinator and the local community health center on a weekly and monthly basis. From the research results, it can be concluded that the performance of Jumantik in Tembalang subdistrict even though it has carried out its duties, has not met the good performance criteria. This is due to several obstacles that arise. The existence of a dense population and an uneven location in Tembalang Subdistrict causes the quantity of work to be not fulfilled. Likewise, the reporting process is often delayed, because there are many forms that must be filled in.

\section{References}

[1] K. Sudarmanto, "Pengembangan Kompetensi SDM," Yogyakarta: Pustaka Pelajar, 2009.

[2] H. Fattah, "Perilaku pemimpin dan kinerja pegawai," Yogyakarta: Elmatera, 2014.

[3] S. P. Robbins, T. A. Judge, and R. Saraswati, "Perilaku organisasi." -, 1919. 